\title{
The Meaning of Embedded Arabic in Japa-Mantra in Banyakan Village, Kediri, East Java
}

\author{
$1^{\text {st }}$ Hawa Intan Malayyana Sari \\ Javanese Studies Program, Faculty of \\ Humanities \\ University of Indonesia \\ Depok, Indonesia \\ hawa.intan@ui.ac.id
}

\author{
$2^{\text {nd }}$ Widhyasmaramurti* \\ Linguistics Department, Faculty of \\ Humanities \\ University of Indonesia \\ Depok, Indonesia \\ widhyasmaramurti.s@ui.ac.id
}

\begin{abstract}
Japa-mantra is an oral tradition used for healing and is oftentimes associated with mystical superstitions. It is a legacy bequeathed to generations in Javanese culture. Based on the infiltration of religions in Indonesia, the japa-mantra people know is, apparently, a bilingual mixture between Javanese and Arabic. This issue brings up questions regarding how japamantra is perceived in today's society, specifically by dhukun pijet as those who used japa-mantra, and what meanings of japa-mantra are found within society. Hence, the aim of this research is to explain the meaning of japa-mantra in Javanese society. The research was conducted in Banyakan Village, Kediri, where the population still uses traditional medicine to prevent diseases. Written data from Primbon and oral data from japa-mantra used by the dhukun pijet were used in this research. A qualitative method and Suwito's code-switching theory (1982) were used to obtain the dual-language data meanings. The result of this research showsthat the dhukun pijet in Banyakan Village still understood japa-mantra, which they use as their ancestors' legacy. They prefer to use the oral japa-mantra of their ancestors over the written one. The meaning of Arabic japa-mantra is a prayer to God to heal diseases that is used by the population of Banyakan Village.
\end{abstract}

Keywords-Javanese language, dhukun pijet, functions, japa-mantra, meanings

\section{INTRODUCTION}

Indonesia is a multiethnic nation with hundreds of tribes and various cultures from different regions that unify for the nation under the motto "Bhinneka Tunggal Ika," meaning "Unity in Diversity." Javanese is one of the largest tribes and most prevalent cultures in Indonesia. Traditionally, the Javanese culture covers all central and eastern parts of Java and is divided into central, coastal, and eastern regions. The central region includes Yogyakarta, Banyumas, Surakarta, and Kedu. The northern coastal region includes Tegal, Jepara, Rembang, Pekalongan, and other North Sea coastal areas that are close to the administrative center. Meanwhile, the eastern coastal region includes Malang, Madiun, Nganjuk, Kediri, and areas close to the Brantas River delta [1].

Life in Javanese society always produces a culture that reflects human behavior as social beings. In addition, human life is faced with obstacles, temptations, and problems, one of which is fighting life threatening diseases. As living things and social beings, humans must expand their minds and knowledge in order to find solutions to health problems. Frazer [2], and Koentjaraningrat [3] state that "human solves their life obstacles with mind and knowledge, although it must have its limit." Thus, mystical things and witchcraft are believed to solve obscure problems in life by certain societies to cure diseases. In Javanese, the mystical things still used by society as a means of curing are called mantras. However, most mantras are known as japa-mantra because they are used by traditional healers (shamans) who are specifically called dhukun pijet.

Japa refers to a prayer that is said in a mumbling way [4]. Meanwhile, according to Kamus Umum Bahasa Indonesia [5], a mantra is an incantation that brings magical powers to the chanter. Mantras are one type of folk poetry and include certain forms, such as sentences that are bound by the syllable length, the tone, or the rhythm [6]. Every region has its own japamantra according to the language and meaning, one of which is the Javanese japa-mantra that is still used in some regions. Research on mantras in Javanese has been conducted before. Yoga Wicaksono (2013)[7] wrote a journal article titled "Analysis of Diction and Semantic Concepts of Mantra in Primbon Adjimantrawara by Soemodidjojo Mahadewa," which examined the concepts of diction and semantic in Primbon Adjimantrawara, which was published by Soemodidjo. Barokah Muhazetty (2017)[8] wrote a journal article titled "Mantra in Javanese Culture (Editing Javanese Texts and Pragmatic Studies)." This writing explains 14 kinds of mantras used by the Javanese people in their daily lives, such as for healing, salvation, mercy, quick selling, and guarding houses. Another study on mantras was written by Alfi Qori ah, Wafi Azhari, and Rifqi Muhammad (2018) [9] titled "The Ujub-Ujub Mantra: Its Meanings and Functions in the Community of Karangrejo Village, Malang Regency, East Java." This research focuses on the meaning of the denotations and connotations of the mantra as well as its functions. An important finding of this writing shows that the functions of the $u j u b$ ujub mantras are as symbols for the life of the Javanese, namely symbols of humanity, cultural, fertility sustenance, and salvation. The difference between the previous research and this work is that the previous studies merely focused on the meanings of

${ }^{1}$ This part had been presented at the $7^{\text {th }}$ Annual International Linguistics Seminar 2019 on June $29^{\text {th }}-30^{\text {th }}$ and published in the journal of the $7^{\text {th }}$ Annual International Linguistics Seminar 2019 Language Existence in Industry 4.0 ISBN 978-602-6666. This paper is a development from the journal article and has more data research (7 gugon tuhon data while the article has five data) and discussion that more focus on cross-generation cultural transfer conducted by mothers. 
the Javanese mantras, whereas this writing looks more at the embedded Arabic lexicons in Javanese mantras. As the Islamic religion grows in Indonesia, it is common to have both the Javanese and Arabic languages used in society's daily life, including by those in Banyakan Village, Banyakan District, Kediri Regency, and East Java.

Banyakan Village is one of villages divided into eight smaller areas or hamlets. The majority of the population there works as farmers, chicken ranch owners, and banyak, or white swan seller. In order to show their concern for the environment, they work together to do community services. They also still practice traditional ways of doing arts, ceremonies, and medication. Some examples of the traditional medication include dhukun bayi for childbirth and dhukun pijet for curing disease, even though they are already familiar with paramedics or doctors.

The japa-mantra used as the data of this research are found in a literature study from Primbon Japamantra by Aji Margono [10] and gathered from interviews with dhukun pijet (shamans) in Banyakan Village. The shamans that apply japa-mantra are divided into the dhukun putih (white shamans) and the dhukun hitam (black shamans). The white shamans are those who can treat patients. Meanwhile, the black shamans, also known as dhukun santet, are those who can put spells on someone, usually in a form of black magic (santet), yet they also treat patients.

It is not clearly known when japa-mantra appeared in Indonesia, but it was after Islam entered Java. This has been proven because japa-mantra incorporates Arabic and Javanese and alludes to the use of code switching. Suwito [11] states that code switching is the phenomenon of switching from one code (language) to another code (language). An example of code switching is if a speaker is speaking in Javanese and then switches to Arabic or the other way around. The act of switching from one language brings up the issue of the meanings and functions of Arabic in japa-mantra used by the dhukun pijet and how they perceive the meanings. Hence, the aim of this research is to explain the meanings and functions of Arabic in japa-mantra and to understand how the dhukun pijet perceive this meaning within Javanese society.

The research took place in Banyakan Village, Banyakan District, Kediri Regency, East Java. The interviews were conducted with three out of five informants who are all dhukun pijet in that village; two people were not willing to be informants. The three informants were chosen because they were willing to share their spells (mantras) and related information. They are local residents who are respected and viewed as community leaders because they have special merit. Banyakan Village was chosen because the dhukun pijet are still found there and are trusted by the population in the village.

\section{RESEARCH METHODS}

This research used a qualitative method through a literature study and interviews, and the data collection steps are as follows:

\section{A. Written data collection}

The written data in this research include four different japa-mantra in a literature study from Primbon Japa-mantra by Aji Margono from 1985[10]. These data were taken to the field for interviews with dhukun pijet in Banyakan Village, Kediri Regency, East Java. The interviews were conducted on January 11-27, 2019. Based on the results of the interviews, three japa-mantra that are used by the dhukun pijet were found, resulting in seven japa-mantra data sources.

\section{B. Research target and location}

The research target was the dhukun pijet in Banyakan Village, Kediri Regency, East Java. They were chosen because research on japa-mantra is related to medical treatment, and thus the dhukun pijet are considered appropriate. The research was conducted in Banyakan Village, Kediri Regency, East Java. The interviews were conducted with three informants whose main profession is working as dhukun pijet. There are five dhukun pijet in Banyakan Village; three of them were willing to be informants, whereas two were not. The three informants were chosen because they were willing to reveal their spells and share information. They are local residents who are respected and viewed as community leaders due to their special merit. Banyakan Village was chosen because the dhukun pijet are still found there and are trusted by the population in the village.

\section{Data collection result}

This research used Suwito's sociolinguistics theory [11], which argues that code switching is changing from one code (language) to a different code (language). Code switching occurs due to a dependency relationship within speech community. The uses of bilingual and multilingual approaches are divided according to the following: a) every language must carry its own functions and roles according to the context; and b) every function of the language must be adjusted in a situation that relates to the context change. Suwito divides code switching into internal code switching and external code switching. Internal code switching occurs among native languages as a first language, for example, between Sundanese and Javanese, which are both native languages in Indonesia. On the other hand, external code switching occurs between a foreign language and a first language, for example, between Arabic and Indonesian. Jendra (2001) [12] argues that code switching is a state in which a speaker changes the code (language) intentionally for a certain reason. The same goes for Pietro (1977) in Jendra (2001)[12], who argues that "code switching is the use of more than one language by communicants in the execution of a speech act."

\section{RESULTS AND DISCUSSION}

The following includes an explanation of the analysis of the meanings of japa-mantra based on the data processing acquired from literature study and interviews: 
1. Bismillah hirrohmaan nirrohiim. Assalaamu`alaikum. Malaekat petangpuluh papat rumeksanen pribadiku lamun badan kula piyambak, lamun dhateng pasien, pribadine si suta. Sing seja ala balekna, lamun ora gelem bali patenana. Sira ya ingsun sokhabate kanjeng Nabi Muhammad kang sampurna. Kun wadhah ngelmu, faya kun tutuping ngelmu. Laailaaha illallahu Muhammaddarosulullah.

"In the name of Allah, the Most Gracious, the Most Merciful. Assalaamu `alaikum. Forty-four angels, take care of my soul and my body, and to the patient, take care of the child's soul as well. Forgive those who deliberately trespass against You and end those who do not want to be forgiven. You are the closest companion of the perfect Prophet Muhammad. Be a vessel and also the lid of knowledge. There is no god but God and Muhammad is the messenger of God."

The first japa-mantra is from an interview with Mbah Wiji Sri Mujiati (80 years old), who has worked as a dhukun pijet for 46 years. Based on this japa-mantra, it can clearly be seen that Mbah Wiji did code switching in the first sentence she chanted: "Bismillah hirrohmaan nirrohiim. Assalaamu alaikum. Malaekat petangpuluh papat rumeksanen pribadiku lamun badan kula piyambak." After switching to Arabic, the japa-mantra was chanted in ngoko and krama Javanese. Ngoko is a language of manners in Javanese used between people who are close or with someone younger [5]. Meanwhile, krama is a language of manners in Javanese used between people who have just met or with someone older [5]. Code switching in the first sentence shows the speaker's ability and skills in uttering the japa-mantra according to its function, situation, and context [11]. The function of code switching in this japa-mantra is based on the belief that Arabic could make the japa stronger. Situations in which code switching happens is sacred; it is when the shaman will do the act of massaging. The context of code switching is treating a patient who will be massaged.

In the middle part of the spell, the chanter said, "Nabi Muhammad kang sampurna," meaning "the perfect Prophet Muhammad," as a praise to God's emissary. Then, the spell is closed with "Sing seja ala balekna, lamun ora gelem bali patenana. Sira ya ingsun sokhabate kanjeng Nabi Muhammad kang sampurna. Kun wadhah ngelmu, faya kun tutuping ngelmu. Laailaaha illallahu Muhammaddarosulullah." The code switching in this part occurs in the last two sentences, which are "Kun wadhah ngelmu, faya kun tutuping ngelmu. Laailaaha illallahu Muhammaddarosulullah." After the word "Kun," meaning "to be" in Arabic, the phrasing switches to Javanese with the phrase "wadhah ngelmu," meaning "vessel of knowledge." Next, code switching also occurs in the phrase "faya kun tutuping ngelmu." At the end of the spell, the code switching shows embedded Arabic in the Javanese japa-mantra. The code switches back to Arabic in the japa with the words "faya kun tutuping ngelmu. Laailaaha illallahu Muhammaddarosulullah." Both internal and external code switching occurs in this part because there is a switch from Javanese, which is a local native language, to Arabic as a foreign language. This japa-mantra is used by the dhukun pijet to treat gregesan or feverish babies, children, or adults.
2. Jopa-japu pinjal tumane asu, set grewal-grewel sete segudel-gudel. Tuntum adhem asrep ketiban idu putih. Ya Allah... jabang bayine (.jenenge wong tuwa.) mugi-mugi diparingi jodho waras waras waras saking kersane Allah. Lāhaulawalāquwwataillābillāhil'aliyyilazhīm.

"Jopa-japu pinjal dog fleas, slithery maggots as big as a calf. Be healed by saliva. O God... with the blessings of God please give child (parents' name) a healthy spouse. There is no power and efforts but Your power, the Most High, the Most Great."

The second japa-mantra is from an interview with Mrs. Siti Mahmudah (55 years old), who has worked as a dhukun pijet for approximately seven years. Based on this spell, it can clearly be seen that there is a repetition of the word "japa" in the word "jopa-japu," which in Javanese is called "dwilingga salin swara" [13]. The rhyme at the end of the word " $a s u$ " falls in the sound " $u$," and thus this choice of word meets the end of the word "japu." The resemblance of sound at the of these words is called purwakanthi guru-swara, which is the repetition of vowels at the end of a sentence [13]. The word "set" means "maggots" [5], while "grewel-grewel" means "slippery," and "gudel" means "calf." The phrase "slithery maggots as big as a calf" is a parable that maggots are the same size as calves.

Next, to align the sound "el" at the end of the sentence, "grewel" is put together with "gudel." The words "gudel" and "grewel" fall with the same guru-swara that is el. At the end of the japa-mantra, there is code switching from Javanese to Arabic in the sentence "mugi-mugi diparingi jodho waras waras waras saking kersane Allah.. Lā haula walā quwwata illā billāhil 'aliyil adzīm," which means "There is no power and efforts but Your power, the Most High, the Most Great." As stated by Jendra [12], code switching occurs for a "reason." The reason for code switching at the end of the spell is to end the japa with hope that the speaker will get strength from God to heal patients. The code-switching process is a manifestation of the speaker who asks for God's permission to end the mantra and begin massaging immediately.

The function of this japa-mantra is due to the belief that the emergence of Arabic will make the chant more effective. The situation of code switching at the beginning of the spell is sacred, where the dhukun pijet ends the chant and begins massaging. The context of the code switching is to heal patients who will be massaged, specifically babies. When the sentence "ketiban idu putih" is chanted, the dhukun will spit a little and apply the saliva to the baby's umbilical cord. The saliva is usually mixed with betel leaves, charcoal, and turmeric. It is believed this could accelerate the dryness of the umbilical cord, so it is released from the baby's navel immediately [14]. To begin the activity of massaging, the name of the parents of the baby must be uttered.

3. Bismillahhirrohmaannirrohiim. Pegangan Hyang Resi, pring ireng bapake Semar, tangan kiwa tangan tengen, taktamakake jabang bayine (jenenge wong tuwa.) sing takpijet saka welas 
asih, asihe Gusti Allah mugi-mugi ampuh mandi waras saking kersaning Gusti Allah Ta`ala.

"In the name of Allah, the Most Gracious, the Most Merciful. Holding on to Hyang Resi, the black bamboo of Semar, left hand right hand, I touch this child of (the name of the parents) whom I massaged with affection from God, please be healed with the blessing of God."

The third japa-mantra is from an interview with Mrs. Suyati (51 years old), who has worked as a dhukun pijet for 13 years. Mrs. Suyati did code switching at the beginning of the spell with "Bismillahhirrohmaannirrohiim. Pegangan Hyang Resi, pring ireng bapake Semar"; she switched from Arabic to ngoko Javanese. In terms of Javanese puppet play, known as wayang, the father of Semar is Sang Hyang Tunggal [15]. The Javanese consider Semar to be the guardian of the knights and guides because he guards Pandawa, who is the ancestor of the Javanese. This is a form of trust in Semar, given that he is the guardian spirit of Java and the world [16]. Therefore, the appearance of Semar in this spell is important. In this spell, the dhukun pijet use both palms rubbed together as a medium for massaging as the spell is chanted. After this, the dhukun will begin the act of massaging the baby, followed by saying the baby's parents' names. This japamantra is used to treat babies' diseases.

The phrase "Hyang Resi" shows that spells in Hinduism are passed down by the Almighty God to humans through God's emissary, a deity, and then are passed on to someone who has a certain quality, a sage [14]. A sage is a hermit or a saint [5]. In this japamantra, the chanter shows that a little bit of Hindu influence still exists in the spells.

4. Bismillahhirrachmanirrahimi, ora ana kang bisa aweh katis, amung aku kang bisa aweh katis, jatingarang katisanan, si (sing lara....). anu....... warasa, adem asrep katiban iduku putih, ya hu ya hu.

"In the name of Allah, the Most Gracious, the Most Merciful, no one can give cure but me. the dragon who guards the way of cure, please give (the patient's name) cure by my saliva, ya hu ya hu."

The fifth japa-mantra is taken from Primbon Japa-mantra, written by Aji Margono in 1985, page 30 , number 31 [10]. At the beginning of the spell, there is a code switch from Arabic to ngoko Javanese in the sentence "Bismillahhirrachmanirrahimi, ora ana kang bisa aweh katis." As stated by Pietro (1977) in Jendra [12], code switching occurs when the speaker has more than one language skill. In this spell, the chanter begins with Arabic, stating "Bismillahhirrachmanirrahimi," followed by ngoko Javanese in the sentence "ora ana kang bisa aweh katis" to show that the chanter has mastered both languages. Through this spell, the chanter shows her power in the sentence "no one can give cure but me."

The word "jatingarang," meaning 'the dragon who guards the way of cure," refers to beliefs in the jatingarang dragon that is often the symbol of the change in year, month, and day. The jatingarang dragon is also believed to be used as the petungan, or guard, of the way [17]. It can be seen in this spell that the shaman chanted this by spitting on the patient who is suffering from katisan, or a cold, so that the patient will be healed (waras). The function of the saliva mentioned in this spell is as a mixture of topical oil and eucalyptus oil to make the activity of massaging easier for the shaman as it makes the skin smooth.

\section{Assalaamualaikum (kaping 3) angin Allah kang} ana sirah metuwa, yen ora metu kena dukane Allah (kaping 3)

"Assalaamualaikum ( 3 times) the wind inside the head come out, if it does not God will give His anger (3 times).'

The fifth japa-mantra is taken from Primbon Japamantra, written by Aji Margono in 1985, page 30, number 32 [10]. At the beginning of the sentence, Arabic is embedded into Javanese as code switching to say a greeting. The speaker chants the spell in the hope that the wind inside the patient's head will be released or else God will be angry. This spell is used to cure headaches.

The word "angin" in this spell refers to the wind as the cause of the headache. According to Traditional Chinese Medicine, headaches occur because a wind pathogen enters the head. The pain that the patient suffers from is called Tou Feng [18]. This confirms that the spell is used for treating patients who suffer from headaches by massaging the head so that the wind (the illness) will leave.

6. Encak-encak ale, si ale kebo jagitan, anak-anak kebo dungkul si dungkul gage warasa, waras saking kersaning Allah (kaping 3).

"Bamboos made for offerings, the devil in a form of buffalo, calves with curved horn please be healed by the blessings of God (3 times)."

The sixth japa-mantra is taken from Primbon Japamantra, written by Aji Margono in 1985, page 30, number 33 [10]. There is a writing error in this spell for the word "kebo jagitan," which means "the buffalo's head devil," which was supposed to be "kebo jangitan" [5]. In addition, the word "dungkul" is considered inappropriate because it should be "dhungkul," which means "a downward curved horn" [5]. The phrase "encak-encak ale" is usually chanted as "encak-encak alis," which means "the bamboo made for offerings to be walking around to." Apart from being used as a spell, the sentence "encak-encak ale, si ale kebo jagitan, anak-anak kebo dungkul" is also used as a child's nursery rhyme for playing [19]. The difference between the phrases is located in the functions. As a spell, the function is for medical healing, whereas as a nursery rhyme, it is used for entertainment.

7. Sokang saking sancaya gurda wanuh tur wenteh, kukuh-kukuh, saking karsaning Allah (kaping 3).

'Dari kumpulan pohon beringin yang bersatu juga terlihat jelas, kuat-kuat, atas restu Allah` (3 times)

The seventh japa-mantra is also taken from Primbon Japa-mantra, written by Aji Margono in 1985, page 30, 
number 34 [10]. The word "sokang-saking" is a repetition with a change in sound (dwilingga salin swara) in the word "saking," which means "from." Next, the word "gurda" means "Banyan tree" [5]. Then, the word "kukuh-kukuh" means "unbreakable or strong." It is believed through the philosophy of the benefits of Banyan trees that the bark, roots, and leaves carry polyphenol, flavonoids, and saponins to give nutrients to the teeth and treat dental caries [20]. Therefore, a patient who suffers from a toothache is expected to be healed and have strong teeth like the Banyan tree with God's blessings.

The seven code-switched japa-mantra all have nearly the same functions, situations, and contexts. Code switching in all the spells shows that there is both internal code switching and external code switching that are merged into one in the first five japa-mantra. In general, internal code switching occurs only within native languages, whereas external code switching occurs between a foreign language and a first language. However, Javanese and Arabic, which are internal and external languages, are spoken in one sentence in turn. This issue is unique because japa-mantra are chanted in two different languages.

All data show that the meanings of the japa-mantra perceived by the dhukun pijet are that they are intended as prayers to ask for healing and safety for those who are sick. The event of code switching is different in each spells, yet they have the same principal at the beginning and end of the sentences as they all mention God or Allah to show that the shaman is asking God to heal the patient. Code switching in japa-mantra occurs for three reasons: 1) Arabic as a language is believed to have a close relation to God, so it can heal people; 2) Javanese is their first language and is dominantly used by the speakers (dhukun pijet) while performing their job; and 3) The code switching that is occurring is internal and external between Javanese and Arabic.

The code switching in all data is considered unique due to Javanese being the speaker's first language, and Arabic is a form of engagement they have with God. Javanese is used as the dhukun pijet have Javanese cultural backgrounds, and Arabic is used as a form of faith so they can be closer to God and their prayers will be answered.

TABLE I. CODE SWITCHING

\begin{tabular}{|c|c|c|}
\hline NO & Code Switching & $\begin{array}{c}\text { Meanings and } \\
\text { Functions }\end{array}$ \\
\hline 1. & Bismillahhirrohmaannirrohiim & $\begin{array}{c}\text { For the beginning } \\
\text { of the spell (japa- } \\
\text { mantra) that is } \\
\text { intended to God. }\end{array}$ \\
\hline 2. & Assalaamu alaikum & $\begin{array}{c}\text { Greetings said by } \\
\text { the shaman } \\
\text { (dhukun) }\end{array}$ \\
\hline 3. & Kun wadhah ngelmu, fayakun tutuping \\
ngelmu. & $\begin{array}{c}\text { The end of the } \\
\text { spell. }\end{array}$ \\
\hline 4. & $\begin{array}{c}\text { Laailaaha illallahu } \\
\text { Muhammaddarosulullah. }\end{array}$ & $\begin{array}{c}\text { The end of the } \\
\text { spell that is } \\
\text { intended to God } \\
\text { and the Prophet. }\end{array}$ \\
\hline
\end{tabular}

\begin{tabular}{|c|c|c|}
\hline 5. & $\begin{array}{c}\text { Lä haula wa lä quwwata illā billähil } \\
\text { aliyyilazhīm }\end{array}$ & $\begin{array}{c}\text { The end of the } \\
\text { concluding of the } \\
\text { spell that } \\
\text { explains that } \\
\text { there is no power } \\
\text { that could match } \\
\text { God's power. }\end{array}$ \\
\hline 6. & Allah (kaping 3) & $\begin{array}{c}\text { The final } \\
\text { conclusion where } \\
\text { the shaman puts } \\
\text { everything in } \\
\text { God's hands. }\end{array}$ \\
\hline 7. & Gusti Allah & $\begin{array}{c}\text { The final } \\
\text { conclusion in } \\
\text { which the } \\
\text { shaman } \\
\text { surrenders to } \\
\text { God. }\end{array}$ \\
\hline
\end{tabular}

Arabic is embedded in the spells because there is dominance in the language that has been mastered by the shaman and the belief that it could make the spell more powerful. This shows that code switching occurs in every spell. The transition from Hinduism to Islam and Javanese in Indonesia is the beginning of embedding Arabic into the seven japa-mantra. However, the impact of Hinduism and Islam cannot be determined because the spells do not use ancient Javanese so that society still understands the language. The code switching occurs purely between Arabic and ngoko and krama Javanese rather than ancient Javanese or Sanskrit.

The relation between japa-mantra and millennial issues is related to education, employment, and entrepreneurship. In education, japa-mantra is taught from generation to generation and must be preserved. While for employment, Javanese society has the potential to expand their skills to use japa-mantra as dhukun pijet. As for entrepreneurship, the shaman could create a learning center to teach japa-mantra. In this way, they will be able to strive for the economic element, although they will not set a fixed rate because they believe people who focus on material things cannot develop their skills [21].

\section{CONCLUSION}

Japa-mantra is a part of Javanese oral tradition that is bequeathed from generation to generation by ancestors. It is believed to be a medium between the dhukun pijet (the shaman) to ask God for a patient's recovery. The meaning of the japa-mantra used by the shaman is a form of prayer when they treat a patient. The code switching that occurs by embedding Arabic into the japa-mantra uses both internal and external code switching. The Javanese do not think of Arabic as a foreign language (external) because both Arabic and Javanese are used to communicate to The Creator. The use of the first language (Javanese) in prayers is considered to create a close relationship with God, while embedding Arabic is believed to grant the prayer. Thus, the japa-mantra is chanted in Javanese and Arabic because it is believed that both languages are for communicating with God. The embedded Arabic in the japa-mantra helps the shaman understand the meaning as they believe it could make the spell more effective. 
The shamans perceive the spells from their ancestors as "interns" until they can work on the spells on their own. Hence, they are more confident in using the oral japa-mantra from their ancestors than using the written ones from Primbon. This shows that for them the oral japa-mantra is considered to be stronger. At the end, the suggestion for future research is to do more studies on japa-mantra in other regions to obtain more results about its position in today's modern era because oral traditions must be preserved for the future.

\section{ACKNOWLEDGMENT}

The researchers would like to say thank you to $\mathrm{Mr}$. Manneke Budiman, Ph.D. for his insights in International Young Scholars Symposium on Humanities and Arts 4.0 at Faculty of Humanities, University of Indonesia on July 24, 2019. He told the researchers about the two kinds of shamans (dhukun), which are the white and the black shaman. There are some white shamans who choose not to use black magic even though they can. This research could be developed by looking at the role of the community as to whether there is resistance in the practice of shamanism. Moreover, shamanism could be considered polytheistic in Islam. Then, in relation to entrepreneurship, if paying for a voluntary treatment could improve the standard of living the shaman could be investigated. These insights can make this paper richer with more related information

\section{REFERENCES}

[1] Suseno, F. (2001). Etika Jawa: Sebuah Analisa Falsafi tentang Kebijakan Hidup Jawa (Javanese Ethics: A Philosophical Analysis of Javanese Life Policy). Jakarta: PT Gramedia Pustaka.

[2] Frazer, J.G (1890). The Golden Bough, A Study in Magic and Religion. Abridge edition. New York:St. Martins Press.

[3] Koentjaraningrat. (1990). Pengantar Ilmu Antropologi (Introduction to Anthropology). Jakarta: Rineka Cipta.

[4] MacDonell, A. A. (2006). A practical Sanskrit dictionary. Great Britain: Oxford.

[5] Poerwadarminta, W. J. (1939). Baoesastra Djawa. Groningen: Wolters'UITGEVERS-MAATSCHAPPIJ N.V.

[6] B Danandjaja, J. (2002). Folklor Indonesia (3rd ed.) (Indonesian Folklore). Retrieved from https://scholar.google.com/scholar?hl=id\&as_sdt=0\%2C5\&q=folklor +indonesia\&btnG=

[7] Wicaksono, Y. (2013). "Analisis Diksi dan Konsep Semantik Mantra dalam Primbon Adjimantrawara terbitan Soemodidjojo Mahadewa (Analysis of Dictation and Semantic Concepts of Mantra in Primbon
Adjimantrawara published by Soemodidjojo Mahadewa)", in Jurnal Program Studi Pendidikan Bahasa dan Sastra Jawa. Universitas Muhammadiyah Purworejo.

[8] Muhazetty, B. (2017). "Mantra dalam Budaya Jawa Suntingan Teks Ajian Jawa dan Kajian Pragmatik (Mantras in Javanese Culture Text Editing Javanese Ajian and Pragmatic Studies)," dalam Jurnal Teks Ajian Jawa. Fakultas Ilmu Budaya Universitas Diponegoro

[9] Qori'ah, A., Wafi, A., Rifqi, M. (2018). "Mantra Ujub-Ujub: Makna Dan Fungsinya Dalam Masyarakat Desa Karangrejo Kabupaten Malang, Jawa Timur (Mantra Ujub-Ujub: Its Meanings and Functions in the Community of Karangrejo Village, Malang, East Java)," dalam Jurnal WACANA: Jurnal Bahasa, Seni, dan Pengajaran, Volume 2, Nomor 2, Oktober 2018. Universitas Nusantara PGRI Kediri.

[10] Margono, A. (1985). Primbon Japa Mantra. Surabaya: Apollo Lestari.

[11] Suwito. (1983). Sosiolinguistik Suatu Pengantar Awal (Sociolinguistics An Early Introduction). Surakarta: Henary Offset

[12] Jendra, M. I. I. (2001). Sosiolinguistics. Yogyakarta: Graha Ilmu.

[13] Padmosoekotjo, S. (1958). Ngenggrengan Kasusastran Djawa I, II. Jogjakarta: Hien Hoo Sing

[14] Fuadi, T. M. (2015). Mengkontruksi Kearifan Lokal dalam Pengobatan Tradisional Reproduksi Oleh Dukun Bayi di Aceh (Construction of Local Wisdom in Traditional Reproductive Medicine by Traditional TBs in Aceh). Prosiding Seminar Nasional Biotik.

[15] Darmoko. (2018). Moralitas Jawa dalam Wayang Kulit Purwa: Tinjauan pada Lakon Laire Semar (Javanese Morality in Purwa Wayang Kulit: An Overview of the Laire Semar Play). Paradigma, $\begin{array}{llll}\text { Jurnal Kajian } & \text { Budaya, } & \text { 5(2), }\end{array}$ https://doi.org/10.17510/paradigma.v5i2.52

[16] Darmoko, D. W. R. M., Prapto, Y. (2004). Laku (Behavior). Depok: Fakultas Ilmu Pengetahuan Budaya Universitas Indonesia.

[17] Yuwono, B. T. (2011). Keris Naga (Latar Belakang Penciptaan, Fungsi, Sejarah, Teknologi, Estetis, Karakteristik dan Makna Simbolis) (Dragon Keris (Background of Creation, Function, History, Technology, Aesthetics, Characteristics and Symbolic Meanings)). Jakarta: Badan Pengembangan Sumber Daya Kementerian Pariwisata dan Ekonomi Kreatif.

[18] Yin, G., Liu Z. (2000). Advanced Modern Chinese Acupuncture Therapy. Beijing: New World Press.

[19] Dharmamulya, Sukirman. (2005). Permainan Tradisional Jawa (Javanese Traditional Game). Yogyakarta: Kepel Press.

[20] Tari, C., Agung, P. W. M., Aulanni'am. (2012). Potensi Bioaktif Akar Gantung Pohon Beringin (Ficus benjamina L.) terhadap Aktivitas Protease dan Gambaran Histopatologi Sel Alveoli Pada Tikus (Rattus norvegiccus) yang Dipapar Asap Rokok. Jurnal Program Kedokteran Hewan, Universitas Brawijaya

[21] Williams, W. (1995). Mozaik Kehidupan Orang Jawa: Wanita dan Pria dalam Masyarakat Indonesia Modern (The Mosaic of Javanese Life: Women and Men in Modern Indonesian Society). Jakarta: Pustaka Binaman Pressindo 